\title{
PEMBUATAN SERBUK JAHE SEBAGAI MINUMAN KESEHATAN BAGI WARGA KELURAHAN KAHURIPAN KECAMATAN TAWANG KOTA TASIKMALAYA
}

\author{
Diah Nurlita ${ }^{1}$,Nuri Handayani ${ }^{2}$, Lulu Setiyabudi ${ }^{3}$ \\ 1,2,3 Jurusan Farmasi, Politeknik Kesehatan Kemenkes Tasikmalaya, diahnsutardjo@gmail.com
}

\begin{abstract}
ABSTRAK
Abstrak: Indonesia memiliki kekayaan bahan alam yang cukup banyak. Berbagai jenis tanaman obat pun banyak ditemukan di Provinsi Jawa Barat, khususnya Kota Tasikmalaya. Program ini bertujuan untuk meningkatkan pengetahuan dan ketrampilan masyarakat Kelurahan Kahuripan, Kecamatan Tawang dalam pembuatan serbuk jahe sebagai minuman kesehatan. Metode kegiatan ini adalah menggunakan metode penyuluhan dan pelatihan terhadap kurang lebih 20 orang warga di wilayah Kelurahan Kahuripan. Setelah masyarakat dapat membudidaya tanaman jahe, lalu memproduksi serbuk jahe, maka serbuk jahe tersebut akan dipasarkan di daerah Kota Tasikmalaya dan sekitarnya.Metode yang digunakan yaitu dengan melakukan transfer ilmu melalui penyuluhan dan pelatihan dari tim Dosen Jurusan Farmasi Poltekkes Kemenkes serta melakukan praktek langsung dalam pembuatan produk minuman jahe dalam bentuk serbuk dan pengemasannya. Penyuluhan dan Pelatihan pembuatan minuman kesehatan dari Serbuk Jahe Instan telah dilaksanakan di Kelurahan Kahuripan, dengan sasaran Ibu Rumah Tangga yang berkomitmen untuk mengikuti proses Ipteks bagi Masyarakat berupa penyuluhan dan pelatihan pembuatan minuman kesehatan Serbuk Jahe Instan yaitu sebanyak 6 (enam) orang.
\end{abstract}

Kata Kunci: serbuk jahe, minuman kesehatan, peningkatan perekonomian

\begin{abstract}
Indonesia has many natural materials. Various types of medicinal plants were found in many provinces of West Java, especially Tasikmalaya City. This program aims to improve the knowledge and skills of Kahuripan Urban Village, Tawang District in the manufacture of ginger powder as a healthy drink. The method of this activity is counseling and training to approximately 20 people in Kelurahan Kahuripan. After the community can cultivate ginger plants, then produce ginger powder, the ginger powder will be marketed in Tasikmalaya and surrounding areas. The method used to transfer knowledge through counseling and training of the team of Lecturer Department of Pharmacy Poltekkes Kemenkes, perform direct practice to make ginger powder and packaging. Counseling and Training of healthy drink making from Instant Ginger Powder has been done in Kelurahan Kahuripan, targeting housewife who is committed to follow the science and technology process for the society in the form of counseling and training of health drink making of Instant Ginger Powder as many as 6 (six) people.
\end{abstract}

Keywords: ginger powder, healthy drink, economic improvement.

Riwayat Artikel: Diterima: 20-12-2017, Disetujui: 30-01-2018 


\section{A. PENDAHULUAN}

Pembangunan kesehatan merupakan perwujudan sehat sebagai hak azasi rakyat dan merupakan investasi bagi pembangunan nasional. Oleh karena itu semua pelaku pembangunan harus memberikan kontribusi positif terhadap peningkatan status kesehatan masyarakat. Salah satu isu pokok dalam pembangunan kesehatan adalah peningkatan pelayanan kesehatan. Upaya yang dapat dilakukan antara lain melalui peningkatan akses dan kualitas pelayanan kesehatan serta peningkatan kemampuan masyarakat dalam pemeliharaan kesehatan. Dalam upaya tersebut ketersediaan obat dalam jenis yang lengkap, jumlah yang cukup, terjamin mutu, khasiat dan keamanannya, harga yang terjangkau serta mudah diakses adalah beberapa faktor penting.

Saat ini sistem pengobatan di Indonesia didasarkan pada sistem pengobatan konvensional menggunakan produk-produk terapi berbasis bahan kimia tunggal. Sejalan dengan meningkatnya perhatian masyarakat terhadap pengobatan tradisional, yang di dalamnya melibatkan penggunaan obat tradisional, baik ramuan tradisional (jamu) maupun formula modern dalam bentuk obat tradisional, pemerintah telah memberikan perhatian yang sangat besar baik dari segi pelayanan maupun regulasi yang menyangkut produk obat tradisional tersebut [1].

Peranan obat tradisonal Indonesia sangat penting dalam pembangunan kesehatan terkait pendekatan preventif dan promotif untuk memelihara kesehatan. Masyarakat banyak memilih pengobatan tradisional karena pengobatan konvensional dipandang mahal dan dapat menurukan kualitas hidup akibat efek samping obat. Kemampuan masyarakat untuk mengobati sendiri, mengenai gejala penyakit dan memelihara kesehatan perlu ditingkatkan dalam rangka menjaga kesehatan. Untuk itu, obat tradisional merupakan potensi yang besar karena sudah dikenal oleh masyarakat, mudah diperoleh, serta sudah merupakan bagian dari sosial budaya masyarakat. Kemauan yang kuat untuk mengembangkan tanaman obat (political will) dari pemerintah daerah dan masyarakat merupakan hal terpenting, dimana keberadaan sumber bahan baku tanaman obat mendorong peningkatan nilai tambah (added value) tanaman obat dan meningkatkan pendapatan para petani.

Data yang bersumber dari Rencana Pembangunan Jangka Panjang Daerah (RPJPD) Kota Tasikmalaya 2005-2025 menunjukkan bahwa Proyeksi penduduk Kecamatan Tawang yaitu 68.917 jiwa tahun 2015, 70.477 jiwa tahun 2020, 72.010 jiwa tahun 2025, sedangkan lahan yang mungkin dikembangkan yaitu 36,12 Ha. Dilihat dari data tersebut di Kecamatan Tawang masih ada lahan yang dimungkinkan untuk membudidaya tanaman obat keluarga khususnya Jahe. Program pengabdian masyarakat ini akan dilaksanakan di Kelurahan Kahuripan 
Kecamatan Tawang, jumlah kepala keluarga (KK) yang berada di Kelurahan Kahuripan yaitu 236 dari total KK yang ada di Kecamata Tawang yaitu 791.

Menurut Gabungan Pengusaha Jamu (GP Jamu), jahe termasuk lima besar bahan baku obat tradisional (BBOT) yang paling banyak dibutuhkan, selain Temulawak, Kencur, Sambiloto dan Pegagan. Menurut BPOM dan KEMENTAN, jahe juga merupakan salah satu tanaman obat yang potensial untuk dibudidayakan selain kunyit, temu lawak, temu ireng, kencur, lengkuas, sambiloto, jati belanda, cabe jawa, lempuyang [2].

Jahe memiliki banyak khasiat dalam dunia pengobatan, diantaranya karminativa (obat kembung), stimulansia (penambah tenaga), diaforetika (memperbanyak pengeluaran keringat), ekspektoransia (obat batuk berdahak) dan amara (penambah nafsu makan). Banyaknya manfaat dari jahe sebagai tanaman obat maka jahe dapat digunakan untuk swamedikasi penyakit. Swamedikasi banyak dipilih masyarakat untuk meredakan/menyembuhkan keluhan kesehatan ringan atau untuk meningkatkan keterjangkauan akses terhadap pengobatan [3]. Berdasarkan data dari laporan Kementerian Kesehatan Republik Indonesia tahun 2012, terdapat 44,14\% masyarakat Indonesia yang berusaha untuk melakukan pengobatan sendiri.

Tujuan program pengabdian masyarakat ini adalah meningkatkan pengetahuan masyarakat Kelurahan Kahuripan Kecamatan Tawang mengenai cara pembuatan serbuk jahe sebagai minuman kesehatan. Selain itu, program ini diharapkan mampu meningkatkan keterampilan masyarakat Kelurahan Kahuripan Kecamatan Tawang dalam pengolahan bahan baku jahe menjadi produk minuman kesehatan yang mempunyai nilai ekonomi lebih tinggi.

\section{B. METODE PELAKSANAAN}

Metode pelaksanaan pada program ini yaitu dengan metode transfer ilmu dan pelatihan dari tim Dosen Jurusan Farmasi Poltekkes Kemenkes Tasikmalaya dibantu mahasiswa kepada warga di Kelurahan Kahuripan Kota Tasikmalaya khususnya terkait pengolahan tanaman Jahe. Target program ini adalah Ibu Rumah Tangga yang mempunyai komitmen tinggi. Luaran program IbM ini berupa pendampingan terbentuknya kelompok masyarakat yang produktif, pengetahuan dan peningkatan keterampilan pengolahan Tanaman Obat Keluarga khususnya Jahe. 
Adapun tahapan pelaksanaan program ini yaitu sebagai berikut:

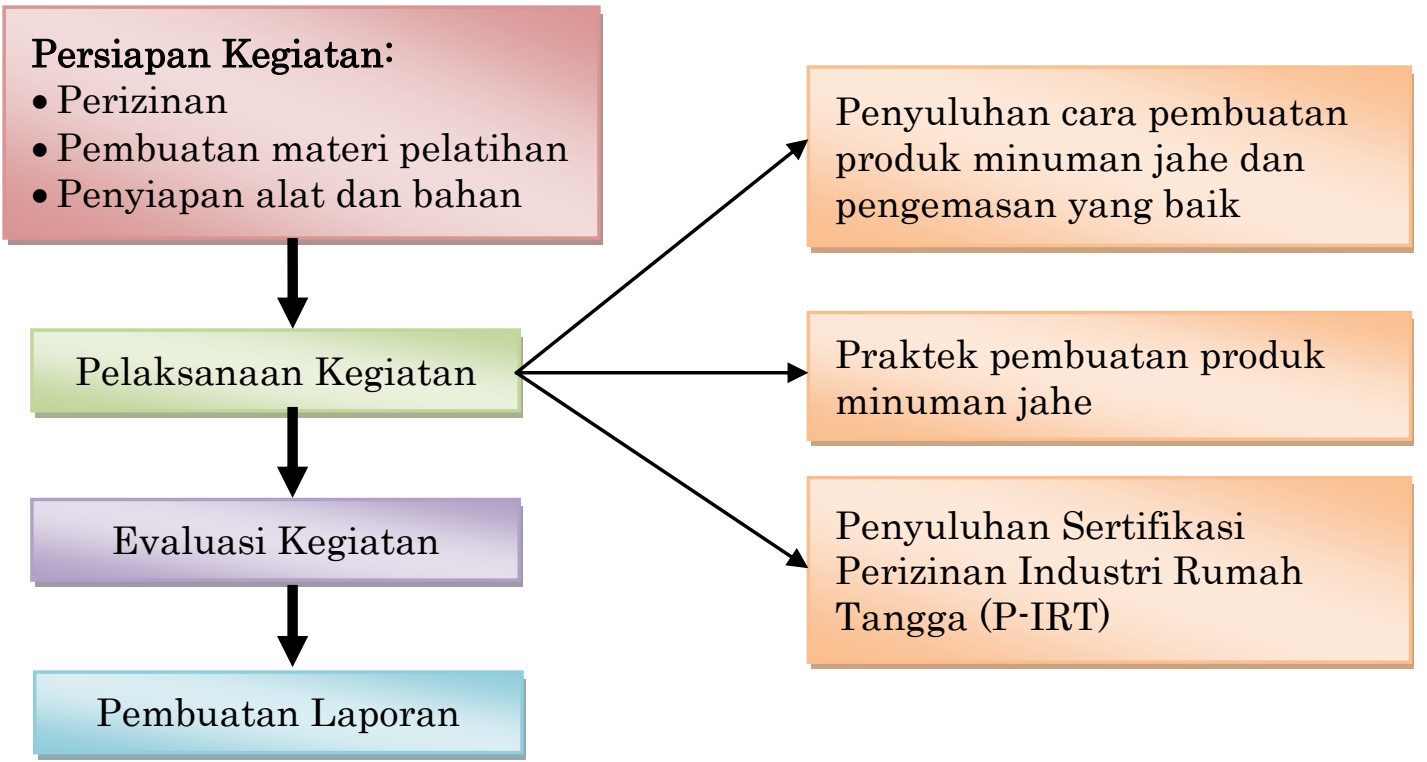

Gambar 1. Diagram Alir Tahapan Pelaksanaan Program

\section{HASIL DAN PEMBAHASAN}

\section{Persiapan dan Pelaksanaan Program}

Program ini dilaksanakan di Kelurahan Kahuripan Kecamatan Tawang Kota Tasikmalaya. Khalayak sasaran dalam program ini adalah masyarakat umum yang memiliki permasalahan terkait rendahnya produktivitas secara ekonomi khususnya ibu rumah tangga di lingkungannya. Hal ini sangat diperlukan untuk membantu Pemerintah dalam menekan kemiskinan dimulai dengan meningkatkan produktivitas masyarakat umum. Pelaksana pengabdian bersama pihak Kelurahan Kahuripan selaku mitra program ini ingin meningkatkan keaktifan ibu rumah tangga sebagai kader di lingkungannya, yang nantinya dapat bermanfaat bagi dirinya, keluarganya, lingkungan sekitarnya, sampai dengan tingkat Kelurahan, Kecamatan dan akhirnya dapat berkontribusi di tingkat Kota Tasikmalaya.

Persiapan program diawali dengan survei tempat pelaksanaan program di wilayah Kelurahan Kahuripan Kecamatan Tawang Kota Tasikmalaya. Hasil survei menunjukkan bahwa ibu-ibu rumah tangga di RW 4 dan 14 yang memiliki komitmen tinggi sebanyak tujuh orang. Pengajuan izin dilakukan kepada pihak Kelurahan Kahuripan dan pemberitahuan kegiatan ke pihak Puskesmas Kahuripan. Selanjutnya, dilakukan persiapan bahan, materi, dan peralatan penunjang untuk pelaksanaan penyuluhan, pelatihan, praktik pembuatan serbuk jahe dibantu oleh mahasiswa serta narasumber untuk penyuluhan.

Pelaksanaan program ini terdiri dari dua tahapan, yaitu penyuluhan dan praktek langsung. Penyuluhan dilakukan untuk memberi informasi seputar pengetahuan produk serbuk minuman jahe. Penyuluhan yang 
dilaksanakan berupa penyuluhan umum tentang tanaman obat keluarga (TOGA) khususnya Jahe, pembuatan serbuk jahe, dan sosialisasi sertifikasi Pangan Industri Rumah Tangga (P-IRT). Dalam kegiatan ini dilakukan evaluasi pengetahuan peserta melalui pre-test dan post-test. Praktek langsung pembuatan minuman serbuk jahe dilakukan di salah satu rumah warga yang melibatkan dosen dan mahasiswa Farmasi Politeknik Kesehatan Kemenkes Tasikmalaya.
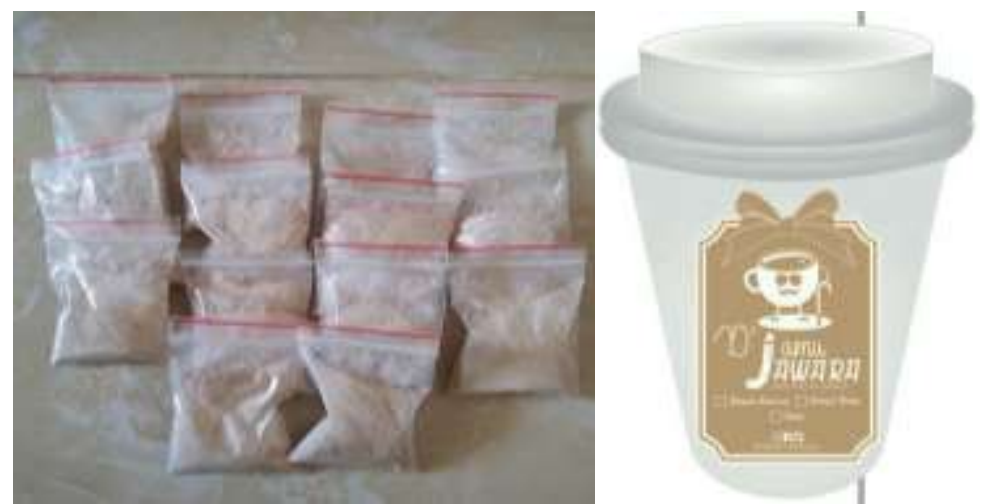

Gambar 2. Produk Serbuk Jahe Instan dan Desain Kemasan Minuman

\section{Evaluasi dan Hasil Capaian Program}

Evaluasi dilaksanakan dengan cara mengukur tingkat pengetahuan sasaran sebelum dan setelah mengikuti penyuluhan. Pengukuran tingkat pengetahuan merupakan salah satu parameter yang dapat menentukan capaian transfer ilmu yang diberikan. Terdapat tiga kategori Tingkat Pengetahuan, yaitu Tingkat Pengetahuan Baik dengan hasil pesentase 76-100\%, Tingkat Pengetahuan Cukup dengan hasil persentase 56-75\%, dan Tingkat Pengetahuan Kurang dengan persentase kurang dari $56 \%$ [4].

Tingkat pengetahuan sasaran sebelum dilaksanakannya program ini sebesar 53,75\% yang termasuk Tingkat Pengetahuan Kurang. Setelah dilaksanakannya program ini tingkat pengetahuan sasaran meningkat, yaitu sebesar 86,25\% sasaran telah memiliki Tingkat Pengetahuan Baik. Peningkatan pengetahuan yang signifikan menunjukkan bahwa program ini berhasil dan sesuai target yang diharapkan.

Sesuai dengan target awal program ini adalah tersampaikannya transfer ilmu dan keterampilan terkait pembuatan serbuk jahe minuman kesehatan instan yang ke depannya akan dilaksanakan pendampingan dalam hal penyempurnaan produk, pengemasan, produksi massal, perizinan dan pemasaran produk untuk wilayah Tasikmalaya dan sekitarnya. Berikut gambar contoh produk Serbuk Jahe Instan yang berhasil dibuat bersama kelompok sasaran dari Kelurahan Kahuripan dan mahasiswa Politeknik Kesehatan Kemenkes Tasikmalaya. 
Dalam pelaksanan program ini terdapat faktor pendukung dan kendala. Faktor pendukung dalam pelaksanaan program ini antara lain adanya kerjasama yang baik di internal Tim Pelaksana program. Selain itu, adanya dukungan kuat dari instansi dan pihak terkait juga memperlancar pelaksanaan program ini. Namun ada beberapa hal yang menjadikan program ini agak terhambat, antara lain manajemen waktu pelaksanaan program yang masih kurang serta komitmen khalayak sasaran yang belum optimal (hanya 7 dari 20 orang yang memiliki komitmen tinggi).

\section{SIMPULAN DAN SARAN}

Pengetahuan masyarakat Kelurahan Kahuripan telah meningkat dari Tingkat Pengetahuan Kurang (53,75\%) menjadi Tingkat Pengetahuan Baik (86,25\%). Masyarakat Kelurahan Kahuripan telah memiliki keterampilan dalam pengolahan bahan baku Jahe menjadi sediaan yang mempunyai nilai ekonomi yang lebih tinggi telah terlaksana. Program tindak lanjut dari program ini adalah melanjutkan program tahun ini, yaitu meningkatkan kemandirian ekonomi masyarakat umum dalam pengolahan tanaman jahe dalam bentuk serbuk untuk minuman kesehatan instan.

\section{UCAPAN TERIMA KASIH}

Tim penulis mengucapkan terima kasih kepada Unit Penelitian dan Pengabdian kepada Masyarakat (UPPM) Politeknik Kesehatan Kemenkes Tasikmalaya yang telah mendanai program ini melalui DIPA Poltekkes dan pihak Kelurahan Kahuripan atas gagasan dan dukungan, sehingga program ini terlaksana dengan baik.

\section{DAFTAR RUJUKAN}

[1] Kemenkes RIa, Peraturan Menteri Kesehatan Republik Indonesia Nomor 88 Tentang Rencana induk pengembangan bahan baku obat tradisional, Kemenkes RI, Jakarta, 2013.

[2] Kemenkes $\mathrm{RI}^{\mathrm{b}}$, Komitmen untuk Kesehatan: Kinerja Program Kefarmasian dan Alat Kesehatan 2012, Dirjen Bina Kefarmasian dan Alat Kesehatan, Jakarta, 2013.

[3] Kartajaya, H., "Self Medication”, PT. MarkPlus Indonesia, Jakarta, 2011

[4] Arikunto, Prosedur Penelitian Suuatu Pendekatan Praktik, Ed Revisi VI, Penerbit PT Rineka Cipta, Jakarta, 2006. 


\section{DOKUMENTASI KEGIATAN}

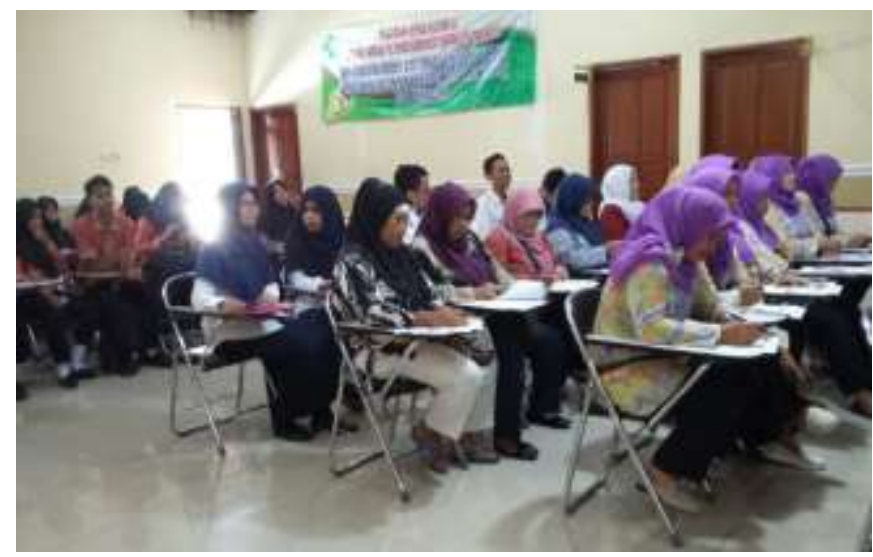

Penyuluhan tentang Produksi Serbuk Minuman Jahe

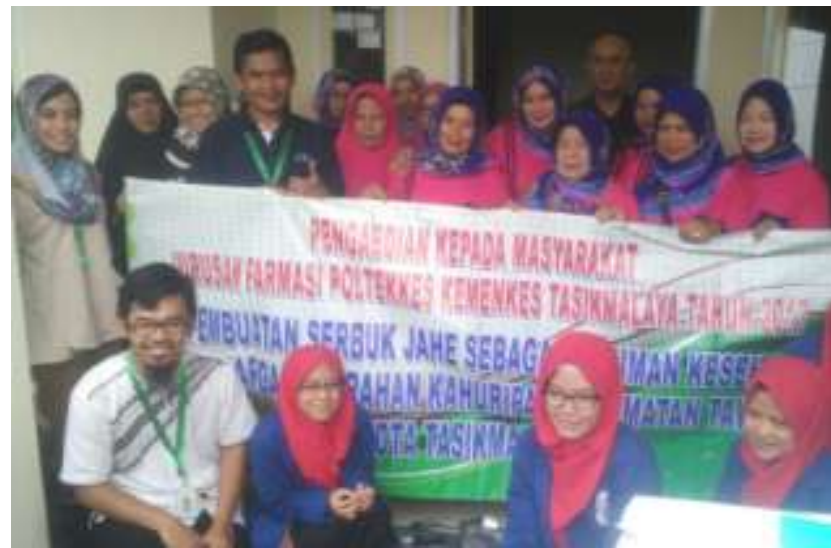

Foto Bersama Warga Binaan Kelurahan Kahuripan Tasikmalaya

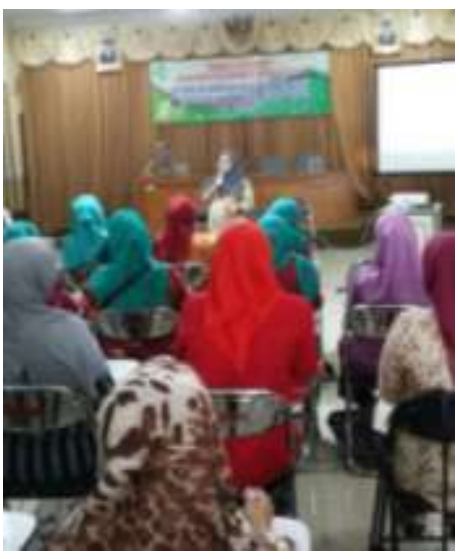

Sosialisasi Sertifikasi Pangan Industri Rumah Tangga

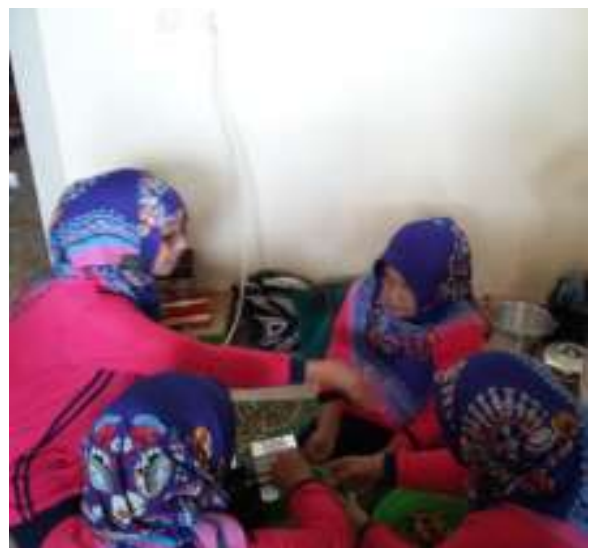

Proses Pembuatan Serbuk Jahe Instan 